\title{
Issues of reconstruction of the history of the Bronze Age of the Khorezm oasis based on the analysis of archaeological data
}

\author{
Matkarimov Khamidbek Olimbayevich ${ }^{1}$ \\ ${ }^{1}$ Urgench State University, Uzbekistan
}

Email:matkarimov x@umail.uz

\begin{abstract}
In the study of archeological monuments of the Bronze Age in the Southern Aral Sea (cultures of Suvorgan, Tozabogyob and Amirabad) Tolstov, Ya.G. Gulyamov and M.I. Itina made a great contribution. The study was conducted in the Akchadarya Delta until the mid-1980s. M.A. Itina's article on the study of bronze monuments in the South Aral Sea covered topography of the Tozabogyob and Amirabad cultures, the causes of the emergence of agricultural culture in the Khorezm region, and the socio-economic relations. The results of studying the Bronze Age cultures of the Khorezm oasis were also reviewed by Khamdam Matyakubov. M.I. Itina's monograph details the archeology of the Bronze Age, including bronze weapons and decorations, stone and bone artifacts, chronology, funeral arrangements, family and social systems.
\end{abstract}

Keywords: Suvorgan, Tozabogyob, Amirabad, Akchadarya Delta, Khorezm oasis.

\section{INTRODUCTION}

M.I. Itina acknowledged that the population of the hillside culture in the Khorezm oasis was nearly one thousand years behind the level of cultivation and cultivators in the southern regions of Central Asia. This situation is observed in the south Aral Sea area. It was preserved until the 7th century BC[1,p.239].

However, some books written in the early 21st century on the history of ancient Khorezm culture, written in a socialist and artistic sense, ignoring archeological reality, argue that Khorezm is the "homeland of early agriculture and crafts" in the Central Asian region. mistakes were made. As a result, publications with similar content have been criticized[2,p.78].

South Aral Sea and southern regions of Central Asia are the main features of the Bronze Age cultures. Khorezm oasis - The wooden pillar is a semi-basement hut made up of fine structure. No brick-andmortar houses, large buildings and defensive structures were absent. Domestic crafts, ceramic utensils are handmade, and ceramics are not applied to crafts. Irrigation agriculture development on small fields farmland. No remains of barley, wheat, oats, millet.

Bactria-Margiana - Raw and brick building, architectural system, architecture - methods of architectural planning. City centers, palaces, temples, defensive walls, apartment buildings. Ceramic pottery Specialized crafts. Findings of grains, fruits and grape seeds.

As can be seen from the table, the Bronze Age architecture and architecture in the Khorezm oasis were relatively underdeveloped with respect to Bactria-Marghian culture. According to H.Matyakubov, S.P. Tolstov, B.V. Andrianov and M.A. Itina has significantly increased the use of artificial irrigated land for agricultural purposes. In fact, according to new archeological data, small canals (ditches) were laid from the Amudarya river's tributaries for artificial irrigation[3,p.20]

A systematic approach is essential in the historical reconstruction of the Bronze Age culture, economy, and social issues. According to the geographical location of the population in the Akchadarya oasis, settlements (Kukcha, Qavat, Kovundi, etc.) consisted of huts, belonging to an average of 3-5 large patriarchal families[1,p.181] The houses are located $50-100-200 \mathrm{~m}$ apart. The land is the property of the seed community and is distributed among individual families. A similar situation was found in the Lower Zarafshan oasis, with natural and geographical conditions close to the environment of the South 
Aral region (Bukhara oasis). In contrast, the Bronze Age Zamonbobo cultures in this region used cairn farming on wetlands[4,p.59]. Bronze Age artificial irrigation facilities were not found in the Bukhara oasis.

The emergence of hollow cultures In the middle of the II millennium BC the Andronovo culture from the Ural-Kazakhstan steppes is associated with the penetration of large groups of cattle tribes into the territory of the South Aral Sea. However, M.A. Itina noted that the purity of hogs dominated the agricultural sector.

A. Askarov suggested that natural conditions in the lower reaches of the Amu Darya, as a primary crop, were conducive to the development of animal husbandry[4,p.84]. Cattle breeding was the basis of Amirabad culture of the IX-VIII centuries BC, while the Bronze Age denied the development of artificial irrigation agriculture in the Khorezm region. X. Matyakubov points out some controversial aspects of the problem and paying attention to Masson's conclusion in this regard. According to this conclusion, the steppe cattle breeding tribes in the Southern Aral Sea, including the Volga and Ural, and the Siberian region, are located on the southern border of the glacier, but this area is the only breeding ground for the Andronovo culture[3,p.19].

Given that the Khorezm oasis is insufficiently studied in the history of the Bronze Age, it should be noted that the southern coast of the Lower Amudarya (Akchadarya oasis) is located in the BC. It has been widely used for artificial irrigation and farming purposes from the $\mathrm{V}$ - IV centuries and especially from the earliest times (III - IV centuries BC). Determining the age of artificial irrigation structures canals, as a result of desertification of ancient irrigated land for centuries, has become a challenge in certain circumstances. There are also seasonal lodges of Tozabogab culture, many cultural sites are not found[5,p.41].

It is known that cattle were grazed on pastures at the beginning of the Bronze Age. They were originally grasslands around the venue. Then there was the seasonal migration, that is, semi-nomadic livestock. Increased population in the steppe areas, overgrazing and overgrazing of natural resources, the need for undeveloped pastures and water resources have resulted in migration to remote areas. Thus, the Bronze Age breeding tribes in Central Asia were widespread across steppes and mountains, including the Aral Sea.

Recent scientific evidence suggests that steppe cattle breeders are found in almost all Central Asian provinces, about one millennium BC. Located in the 16th - 13th centuries BC. Many archeological monuments of Andronovo culture have been found and investigated in the Zarafshan oasis. They consist of settlements, residences, mining facilities - metallurgical centers and burial sites[6,p.37].

The new data will be an important source for examining ethnic and cultural-economic relations. As an example, the Andronovo culture monuments studied in the Zarafshan oasis found silver, gold and bronze earrings and bracelets, and precious stones - sardonic, lavender and turquoise decorations.

Bronze Age metals and mineral deposits are located in the Nurata Mountains and in the Kyzylkum. The development of bronze metallurgy in the communities of the steppe tribes, as well as the steppe tribes, was dictated by the need for ore, such as copper, tin and lead, and the need to manufacture bronze weapons and products. This is why the mining industry is developing rapidly. This is evidenced by the discovery of ore mines and mineral coral workshops near raw materials and mines[7,p.45].

Based on the analysis of archeological data, the history and culture of the Bronze Age of the Khorezm oasis are described as follows:

Material culture. In the South Aral Sea, the Tozabogyap and Amirabad cultures are estimated to have been around. Since the 16th century BC until the VII century BC, 900 years, craftsmanship was developing. Home trades are associated with the manufacture of bones, stone and bronze weapons, and ceramic utensils.

The pottery wheel was not used, so the dishes were made by hand and baked in a bonfire. Although bronze items (knives, sickle, bracelets, needles, arrowheads, ornaments) are different, they are also home-made. In the Yakkaparson 2 Amirabad culture, molds were used to cast bronze sickle and bow arrows. Handicrafts (metalworking, ceramics, jewelry, spinning, and weaving) are not specialized professions. 
The Neolithic Era in the Khorezm oasis was a wooden pillar, built on the ground, and during the Bronze Age semi-basements were used. This way of building homes can be defined by the community's way of life and their ignorance of best building practices[4,p.112].

For us, the centuries-old use of celestial cellars and light booths in the oasis is evidence of the natural habitat and seasonal habitat. Also, the Bronze Age in the Khorezm oasis can be summarized by the slow dissemination of practical knowledge on advanced methods and innovations in the field of architecture and architecture, as the huts were not long-lasting and were carried out by large family members. The new data will be an important source for examining ethnic and cultural-economic relations. As an example, the Andronovo culture monuments studied in the Zarafshan oasis found silver, gold and bronze earrings and bracelets, and precious stones - sardonic, lavender and turquoise decorations.

Bronze Age metals and mineral deposits are located in the Nurata Mountains and in the Kyzylkum. The development of bronze metallurgy in the communities of the steppe tribes, as well as the steppe tribes, was dictated by the need for ore, such as copper, tin and lead, and the need to manufacture bronze weapons and products. This is why the mining industry is developing rapidly. This is evidenced by the discovery of ore mines and mineral coral workshops near raw materials and mines.

Based on the analysis of archeological data, the history and culture of the Bronze Age of the Khorezm oasis are described as follows.

The farm. In the previous pages of this study, the issue of the ratio of agriculture and livestock in the Khorezm region of the Bronze Age was discussed. The publications of the members of the Khorezm Archaeological Expedition claim that agriculture was predominant in the oasis, as the Amu Darya River area adjacent to the Akchadarya oasis had a small area, the use of artificial irrigated land for agricultural purposes, and the storage of agricultural products and food. no special structures were found.

Farming around the coast of the Akchadarya Delta in the form of high-yield farms has not revealed the economic and social development characteristics of local communities. In contrast, steppe conditions in the South Aral Sea were favorable for livestock production.

In the Tozabogab and Amirabad cultures, small and large royal cattle, camels and horse bones were found. The structure of livestock is dominated by small livestock (goats and sheep).

Livestock breeding was an important sector in the economy of the Southern Aral Sea communities, such as the steppe regions of South Ural, Central Kazakhstan and Western Siberia. Livestock plays a leading role in providing the local population with meat, milk, wool, and leather. It is also important to take into consideration the use of oxen, camels and horses for economic activities and as vehicles. The cultures of Tozabogab and Amirabad are part of the Bronze Age steppe culture group. Farming in the cattle steppe tribal farms was an auxiliary basis, mainly for the cultivation of fodder plants on wetlands along the river banks. This crop is called kair (harem) method. The socio-economic system and reconstruction of beliefs. Miles south of the Aral Sea BC In the Bronze Age, there is a rise in culture compared to the Neolithic period of the V - III millennium. The development of the productive forces of the society has been manifested in the fields of animal husbandry, agriculture and metallurgy. As a result of development of metallurgy and animal husbandry in the Eurasian steppe zones, large patriarchal families were formed, which formed the social basis of tribal organization.

\section{CONCLUSION}

According to archeology, the use of bronze armor, labor tools, household items and ornaments was of great importance in the lives of the tribal herders. The production of bronze in Khorezm led to the development of copper, tin and lead deposits in Kyzylkum. Camel and horse breeding has been developed due to the need to use vehicles and vehicles to carry heavy loads both locally and remotely.

\section{REFERENCES}

1. M. Itina. The history of the steppe tribes of the South Aral Sea region (II- beginning of the 1st millennium BC) // Tr. HAEE. T. X - M., 1977.

2. Jabborov I. It is a place of high spirituality and unique culture. - Tashkent: Uzbekistan, 2012.

3. Matyakubov H. Khorezm oasis Bronze Age and Early Iron Age. - Tashkent: National Library of Uzbekistan Publishing, 2017. 
4. Matyakubov H.History of the Bronze and Early Iron Age in the Khorezm oasis (problems of cultural, socio-economic and political relations): History. Philosophy Dr. (PhD) diss ... abstract. Tashkent: National University of Uzbekistan, 2018.

5. Askarov A. Culture of Zamanbab in the lower reaches of Zeravshan // ONU, 1962.

6. Baratov S. Some problems of archaeological research of the ancient cultures of Khorezm // O’zbekiston tarixi, 2007.

7. Gryaznov M.P. Pastoral tribes of Central Asia in the era of developed and late Bronze Age // KSIA. Vol. 122. - M; 1970.

8. Avanesova N.A. Zeravshan version of the Andronovo historical and cultural community // Uzbekistan archeology, mustaillik yillarida. - Samarkand, 2016.

9. Vinogradov A.V. Kyzylkum jewelers // Successes of the Central Asian archeology. - L .: Nauka, 1972. Issue. 2. 